\title{
PEMBERIAN PUPUK BOKASHI MENINGKATKAN PERTUMBUHAN TANAMAN SORGUM MANIS (Sorghum bicolor [L.] Moench)
}

(Giving Bokashi Fertilizer Increases the Growth of Sweet Sorghum (Sorghum bicolor [L.] Moench))

\author{
I. Dewi ${ }^{1 *}$, Rinduwati ${ }^{2)}$, B. Nohong ${ }^{2)}$, \\ ${ }^{1)}$ Mahasiswa Program Strata Satu Departemen Nutrisi dan Makanan Ternak, Fakultas Peternakan, \\ Universitas Hasanuddin. \\ ${ }^{2)}$ Dosen Program Strata Satu Departemen Nutrisi dan Makanan Ternak, Fakultas Peternakan, \\ Universitas Hasanuddin. \\ *Email: indrianidewi96@gmail.com
}

\begin{abstract}
Sweet sorghum is a serellic plant with wide tolerance to climate and soil types and is potential to produce ethanol fuel. The use of sorghum can be used as a source of food, feed, and industry. Increasing sorghum production can be done by using superior varieties and the use of appropriate fertilizers, besides that sorghum can also thrive in growing media that has high nutrient content. Inorganic fertilizers can fulfill nutrients but apart from being expensive, this type of fertilizer has a negative impact on the environment. Overcoming these problems to meet nutrient needs, one alternative that can be done is to use organic bokashi fertilizer. The purpose of this study was to determine the effect of bokashi fertilizer on the growth rate of sweet sorghum (Sorghum bicolor [L.] Moench). This study used a completely randomized design (CRD) consisting of 4 treatments and 4 replications, namely T0: Without Bokashi Fertilizer, T1: Sorghum + Bokashi Fertilizer 300 g / polybag, T2: Sorghum + Bokashi Fertilizer $500 \mathrm{~g} /$ polybag and T3: Sorghum + Fertilizer Bokashi $700 \mathrm{~g} /$ polybag. The highest plant height was T2 $(1.79 \mathrm{~m})$ and the lowest was T0 $(0.58 \mathrm{~m})$. The highest number of leaves was T2 (6.67) and the lowest was T0 (2.33). Based on the results of the research that has been done, it can be concluded that the application of bokashi fertilizer can increase the growth of sweet sorghum (Sorghum bicolor [L.] Moench).
\end{abstract}

Keywords: Number of Leaves, Growth, Bokashi Fertilizer, Sweet Sorghum and Plant Height 
Dewi I, Rinduwati, B. Nohong / Buletin Nutrisi dan Makanan Ternak 14(2) : 41-49

\begin{abstract}
ABSTRAK
Sorgum manis merupakan tanaman serelia dengan daya toleransi yang luas terhadap iklim dan jenis tanah dan potensial sebagai penghasil bahan bakar ethanol. Pemanfaatan sorgum dapat digunakan sebagai sumber pangan, pakan, maupun industri. Peningkatan produksi sorgum dapat dilakukan dengan penggunaan varietas unggul dan penggunaan pupuk yang tepat, selain itu sorgum juga dapat tumbuh subur di media tumbuh yang memiliki kandungan hara tinggi. Pupuk anorganik dapat memenuhi unsur hara tetapi selain harga yang mahal jenis pupuk ini mempunyai dampak negatif terhadap lingkungan. Mengatasi permasalahan tersebut untuk memenuhi kebutuhan unsur hara salah satu alternatif yang dapat dilakukan adalah dengan memanfaatkan pupuk organik bokashi. Tujuan penelitian ini untuk mengetahui pengaruh pupuk bokashi terhadap laju pertumbuhan tanaman sorgum manis (Sorghum bicolor [L.] Moench). Penelitian ini menggunakan Rancangan Acak Lengkap (RAL) yang terdiri dari 4 Perlakuan dan 4 ulangan yaitu T0: Tanpa Pupuk Bokashi, T1: Sorgum + Pupuk Bokashi 300 g/polybag, T2: Sorgum + Pupuk Bokashi 500 g/polybagdan T3: Sorgum + Pupuk Bokashi 700 g/polybag. Tinggi tanaman tertinggi T2 $(1,79 \mathrm{~m})$ dan yang terendah T0 $(0,58 \mathrm{~m})$. Jumlah helai daun tertinggi T2 (6,67 helai) dan yang terendah T0 (2,33 helai). Berdasarkan hasil penelitian yang telah dilakukan dapat disimpulkan pemberian pupuk bokashi dapat meningkatkan pertumbuhan tanaman sorgum manis (Sorghum bicolor [L.] Moench).
\end{abstract}

Kata kunci: Jumlah Helai Daun, Pertumbuhan, Pupuk Bokashi, Sorgum Manis dan Tinggi Tanaman

\title{
PENDAHULUAN
}

Hijauan merupakan sumber pakan utama bagi ternak ruminansia. Produktivitas ternak ruminansia sangat ditentukan oleh ketersediaan pakan yang berkualitas dan berkesinambungan. Sorgum merupakan salah satu tanaman pakan yang memiliki pertumbuhan yang cukup baik dan produksi yang tinggi. Sorgum adalah tanaman serelia penting yang menyediakan energi dan nutrisi bagi manusia dan ternak di seluruh dunia. Sorgum (Sorghum bicolor L.) juga cukup potensial untuk dikembangkan karena memiliki daya adaptasi yang luas, toleran terhadap kekeringan dan genangan air, dapat berproduksi pada lahan marginal, umur panen yang relatif pendek, relatif tahan terhadap hama dan penyakit, serta sorgum tidak memerlukan teknologi dan perawatan khusus. 
Dewi I, Rinduwati, B. Nohong / Buletin Nutrisi dan Makanan Ternak 14(2) : 41-49

Sorgum manis merupakan tanaman serelia dengan daya toleransi yang luas terhadap iklim dan jenis tanah dan potensial sebagai penghasil bahan bakar ethanol. Pemanfaatan sorgum dapat digunakan sebagai sumber pangan, pakan, maupun industri. Sebagai sumber pangan, sorgum memiliki kandungan nutrisi yang tinggi, 332 kal kalori dan 11,0 g protein/100g biji (Koten dkk., 2012). Sebagai pakan, biji sorgum memiliki kandungan nutrisi yang tinggi yaitu, protein 10,26\%, serat kasar 2,72\%, lemak 2,70\%, Ca 0,90, dan P 0,38\% sehingga dapat dibudidayakan sebagai pakan hijauan bagi ternak ruminansia (Wantania dkk., 2018). Sorgum dimanfaatkan di bidang industri dengan pemanfaatan hasil brix/nira dari batang dijadikan sebagai bahan bakar ethanol.

Peningkatan produksi sorgum dapat dilakukan dengan penggunaan varietas unggul dan penggunaan pupuk yang tepat, selain itu sorgum juga dapat tumbuh subur di media tumbuh yang memiliki kandungan hara tinggi. Pupuk anorganik dapat memenuhi unsur hara tetapi selain harga yang mahal jenis pupuk ini mempunyai dampak negatif terhadap lingkungan. Mengatasi permasalahan tersebut untuk memenuhi kebutuhan unsur hara salah satu alternatif yang dapat dilakukan adalah dengan memanfaatkan pupuk organik bokashi. Kandungan pupuk bokashi yaitu $1,34 \% \mathrm{~N}, 0,31 \% \mathrm{P}, 0,54 \% \mathrm{~K}, 2,62 \% \mathrm{Fe}, 1,19 \% \mathrm{Mg}$ dan 1,12\% Ca. Pupuk bokashi memiliki manfaat untuk memperbaiki fisik kimia dan biologi tanah sehingga ramah lingkungan, dapat menyuburkan tanah dan meningkatkan pertumbuhan tanaman, kuantitas dan kualitas produksi tanaman. Oleh karena itu, dilakukan penelitian mengenai pemberian pupuk bokashi meningkatkan pertumbuhan tanaman sorgum manis (Sorghum bicolor [L]. Moench).

Penelitian ini bertujuan untuk mengetahui pengaruh pemberian pupuk bokashi terhadap pertumbuhan tanaman sorgum manis (Sorghum bicolor [L.] Moench). kegunaan penelitian ini sebagai informasi kepada masyarakat tentang pemberian pupuk bokashi dapat meningkatkan pertumbuhan tanaman sorgum manis (Sorghum bicolor [L.] Moench). 
Dewi I, Rinduwati, B. Nohong / Buletin Nutrisi dan Makanan Ternak 14(2) : 41-49

\section{METODE PENELITIAN}

\section{Waktu dan Tempat Penelitian}

Penelitian ini dilaksanakan pada bulan Januari sampai Maret tahun 2020 di Lahan Pastura, Fakultas Peternakan Universitas Hasanuddin, Makassar.

\section{Materi Penelitian}

Alat yang digunakan dalam penelitian ini adalah timbangan analitik, kamera, meteran, dan alat tulis menulis.

Bahan yang digunakan dalam penelitian ini adalah pupuk bokashi, tanah, benih sorgum manis dan polybag.

\section{Metode Pelaksanaan a.Rancangan penelitian}

Penelitian menggunakan rancangan acak lengkap (RAL) (Steel dan Torrie, 1995) terdiri dari 4 perlakuan dan 4 ulangan sehingga diperoleh 16 percobaan. Perlakuan yang diberikan sebagai berikut :

T0 : Tanpa Pupuk Bokashi

T1 : Sorgum + Pupuk Bokashi 60 ton/ Hasetara dengan 300 g/polybag

T2 : Sorgum + Pupuk Bokashi 100 ton/ Ha setara dengan 500 g/polybag T3 : Sorgum + Pupuk Bokashi 140 ton/ Ha setara dengan 700 g/polybag

\section{b. Prosedur penelitian}

Pelaksanaan penelitian dimulai dengan menyiapkan tanah yang akan digunakan. Tanah dihancurkan dan dibersihkan dengan cara diayak. Kemudian 10 kg tanah dimasukkan ke dalam polybag berukuran 30 x $40 \mathrm{~cm}$ dan disiram untuk menjaga kelembaban tanah di dalam polybag. Setelah tanah dimasukkan kedalam polybag, terlebih dahulu dicampur dengan pupuk bokashi sesuai perlakuan level pupuk yang akan diuji. Penanaman dilakukan secara langsung dengan menggunakan benih dengan sistem tugal, dengan 3-5 benih sorgum per lubang. Sebelum melakukan penanaman, dilakukan dengan pemilihan benih terlebih dahulu yaitu memili benih yang bernas (berisi) dan tidak terinfeksi oleh hama penyakit. 
Dewi I, Rinduwati, B. Nohong / Buletin Nutrisi dan Makanan Ternak 14(2) : 41-49

\section{Parameter yang Diamati}

\section{Tinggi tanaman (m)}

Pengukuran tinggi tanaman dilakukan dengan mengukur tinggi tanaman mulai dari pangkal tanaman sampai pada puncak tertinggi daun dengan menggunakan meteran. Pengukuran dilakukan setiap seminggu sekali.

\section{Jumlah Daun (helai)}

Jumlah daun (helai), dihitung semua daun yang muncul, daun yang dihitung adalah daun yang sudah berbentuk daun sempurna (memiliki kelopak daun), dan jika sudah ada daun yang layu (mati) maka daun tersebut tidak lagi dihitung. Jumlah daun (helai) dilakukan seminggu sekali.

\section{c. Analisis Data}

Data yang diperoleh dianalisis statistik dengan menggunakan sidik ragam sesuai Rancangan Acak Lengkap (RAL) 4 perlakuan dengan 4 ulangan dengan model matematikanya adalah :

$$
Y_{i j}=\mu+\pi_{i}+\epsilon_{i j}
$$

dengan :

$\mathrm{i}=1,2,3$, dan 4

$\mathrm{j}=1,2,3$, dan 4

$\mathrm{Y}_{\mathrm{ij}}=$ respon atau nilai pengamatan dari perlakuan ke-i dan ulangan ke-j.

$\mu=$ rata-rata umum.

$\pi_{\mathrm{i}}=$ pengaruh perlakuan ke-i.

$\epsilon_{\mathrm{ij}}=$ pengaruh galat percobaan dari perlakuan ke-i dan ulangan ke-j.

Data yang diperoleh kemudian dilanjutkan dengan analisis Duncan.

\section{HASIL DAN PEMBAHASAN}

Hasil analisis sidik ragam tinggi tanaman dan jumlah helai daun pada tanaman sorgum manis dapat dilihat pada Tabel 1. 
Dewi I, Rinduwati, B. Nohong / Buletin Nutrisi dan Makanan Ternak 14(2) : 41-49

Tabel 1. Rata-rata Tinggi Tanaman dan Jumlah Daun Sorgum yang Diberi Dosis Pupuk Bokashi yang Berbeda

\begin{tabular}{lcccc}
\hline Parameter & \multicolumn{4}{c}{ Dosis Pupuk Bokashi } \\
\cline { 2 - 5 } & $\mathrm{T}_{0}$ & $\mathrm{~T}_{1}$ & $\mathrm{~T}_{2}$ & $\mathrm{~T}_{3}$ \\
\hline Tinggi tanaman (m) & $0,58 \pm 0,06^{\mathrm{b}}$ & $1,69 \pm 0,06^{\mathrm{a}}$ & $1,79 \pm 0,09^{\mathrm{a}}$ & $1,74 \pm 0,14^{\mathrm{a}}$ \\
Jumlah Helai Daun & $2,33 \pm 0,62^{\mathrm{b}}$ & $6,33 \pm 0,27^{\mathrm{a}}$ & $6,67 \pm 0,47^{\mathrm{a}}$ & $6,58 \pm 0,50^{\mathrm{a}}$ \\
\hline
\end{tabular}

Keterangan : huruf yang berbeda (a,b) pada angka rata-rata pada baris yang sama memerlihatkan perbedaan nyata $(\mathrm{P}<0,05)$

Hasil analisis sidik ragam menunjukkan bahwa pemberian pupuk bokashi memberikan pengaruh yang nyata $(\mathrm{P}<0,05)$ terhadap tinggi tanaman sorgum manis. Hasil uji Duncan menunjukkan bahwa pertumbuhan tanaman sorgum T0 berbeda nyata dengan T1, T2 dan T3. Tinggi tanaman yang paling tinggi terdapat pada perlakuan level pupuk bokashi T2 setinggi 1,79 m diikuti T3 setinggi 1,74 m, T1 1,69 $\mathrm{m}$, dan yang paling terendah T0 0,58 $\mathrm{m}$. Hasil penelitian ini lebih tinggi dibandingkan hasil penelitian Bandu dkk. (2018) pada pertumbuhan sorgum brown mid rib dengan menggunakan pupuk bokashi kotoran ayam yang tinggi tanamannya mencapai 113,12 cm. Hal ini menunjukkan bahwa penambahan pupuk bokashi dapat menigkatkan unsur hara $\mathrm{N}, \mathrm{P}$ dan $\mathrm{K}$ dalam tanah dan memengaruhi pertumbuhan tanaman sorgum. Hal ini sesuai dengan pendapat Almodares dan Darany (2006) tanaman sorgum sangat merespon terhadap perlakuan pemupukan, terutama nitrogen. Selama waktu penanaman sorgum manis harus memerhatikan penggunaan pupuk dalam mendorong fase awal pertumbuhan.

Nitrogen merupakan unsur hara terpenting pada fase awal pertumbuhan. Irawan dkk. (2020) menyatakan bahwa dalam fase pertumbuhan vegetatif tanaman unsur hara nitrogen yang paling dibutuhkan, dengan tersedianya nitrogen dalam jumlah yang cukup maka proses berfotosintesis, pembelahan, pemanjangan dan diferensiasi sel berjalan dengan baik. Kebutuhan unsur hara nitrogen pada tanaman sorgum sangat penting dalam meningkatkan pertumbuhan vegetatif tanaman dan jika unsur hara yang tersedia dalam jumlah yang cukup maka tanaman akan tumbuh dan berproduksi dengan baik (Lingga, 2007). 
Dewi I, Rinduwati, B. Nohong / Buletin Nutrisi dan Makanan Ternak 14(2) : 41-49

Tinggi tanaman pada pemberian pupuk bokashi yang berbeda pada T0 berbeda nyata dengan pemberian pupuk bokashi (T1, T2 dan T3). Hal ini disebabkan oleh kandungan pada bubuk bokashi yang sangat responsif pada pertumbuhan tanaman terutama pada tanaman sorgum manis. Hal ini sesuai dengan pendapat Wantania dkk. (2018) pupuk bokashi merupakan pupuk hasil fermentasi limbah pertanian dengan menggunakan EM4 yang mampu memperbaiki kondisi tanah, menekan pertumbuhan mikroba yang menimbulkan penyakit dan memperbaiki efisiensi penggunaan bahan organik oleh tanaman.

Rata-rata jumlah daun tanaman sorgum manis yang diberi pupuk bokashi berbeda disajikan pada Tabel 2. Sidik ragam menunjukkan bahwa pemberian pupuk bokashi memberikan pengaruh yang nyata $(\mathrm{P}<0,05)$ terhadap jumlah daun tanaman sorgum manis. Uji Duncan menunjukkan bahwa jumlah daun T0 berbeda nyata dengan T1, T2 dan T3. Jumlah helai daun tertinggi pada perlakuan T2 yaitu 6,67 dan terendah pada perlakuan T0 2,33. Perlakuan T0 dengan hasil terendah sangat berbeda nyata dengan perlakuan lainnya. Hal ini menunjukkan pemberian pupuk bokashi memengaruhi jumlah daun yang tumbuh. Hal ini sesuai dengan pendapat Bandu dkk. (2018) unsur hara dalam jumlah yang cukup dan seimbang sangat memengaruhi keberhasilan pertumbuhan dan perbanyakan jumlah daun pada tanaman. Pertumbuhan jumlah daun sangat berkaitan dengan fungsi unsur $\mathrm{N}$ yang merupakan komponen klorofil, seiring bertambahnya unsur $\mathrm{N}$ dalam tanah sangat berhubungan dengan pembentukan dan perbanyakan jumlah daun pada tanaman (Kusuma, 2015).

Daun berfungsi sebagai organ utama dalam melakukan fotosintesis dan efektif dalam penyerapan cahaya dan pengambilan karbon dioksida. Semakin banyak daun semakin tinggi fotosintesis yang terjadi ( Silalahi dkk., 2018).

Pertumbuhan dan perkembangan tanaman dibatasi oleh Nitrogen (Ferguson et al., 2010), serta merupakan unsur hara utama dalam pembentukan bagian vegetatif tanaman seperti daun, batang, dan akar (Harshlata et al., 2018). Respon sorgum untuk pupuk nitrogen tergantung pada genotipe, iklim, dan sifat tanah (Sriagtula et al., 
Dewi I, Rinduwati, B. Nohong / Buletin Nutrisi dan Makanan Ternak 14(2) : 41-49

2019), umunya sorgum manis merespon baik terhadap pemupukan, terutama nitrogen (Almodares dan Darany 2006).

\section{KESIMPULAN}

Berdasarkan hasil penelitian yang telah dilakukan dapat disimpulkan bahwa pemberian pupuk bokashi dapat meningkatkan pertumbuhan tanaman sorgum manis (Sorghum bicolor [L.] Moench). Pertumbuhan tertinggi pada pemberian pupuk bokashi $500 \mathrm{~g} /$ polybag.

\section{DAFTAR PUSTAKA}

Almodares, A dan S. M. M. Darani. 2006. Effects of planting date and time of nitrogen application on yield and sugar content of sweet sorghum. Journal of Environmental Biology. 27(3): 601-605.

Bandu, V.S., D.A. Kaligis., Rustandi dan W.B. Kaunang. 2018. Pengaruh level pupuk bokashi kotoran ayam terhadap pertumbuhan sorgum brown mid rib (bmr). Zootek. 38(1): 77-83.

Ferguson, B. J., A. Indrasumunar., S. Hayashi., M.H. Lin., Y.H. Lin., D.E Reid dan P.M. Gresshoff. 2010. Molecular analysis of legume nodule development and autoregulation. Journal of Integrative Plant Biology. 52(1) : 61-76.

Harshlata., G.S. Tomar dan S. Sai. 2018. Effect of planting density and levels of nitrogen on ethanol production of sweet sorghum (Sorghum bicolor [L.] Moench) varieties. The Pharma Innovation Journal. 7(2): 04-07.

Irawan, Z. D., C. Ezward dan D.Okalia. 2020. Pengaruh pemberian pupuk kotoran kerbau dan pupuk urea terhadap pertumbuhan dan produksi sorgum (Sorghum bicolor (L.) Moench. Jurnal Green Swarnadwipa. 9(1) : 46-57

Kusuma, M. E. 2015. Penggunaan dosis pupuk kotoran ternak ayam terhadap pertumbuhan dan produksi brachiaria humidicola pada pemotongan pertama. Jurnal Ilmu Hewan Tropical. 4(1) : 16-20.

Koten, B.B., R. D. Soetrisno., N. Ngadiyono dan B. Suwignyo. 2012. Produksi tanaman sorghum (Sorghum bicolor (L.) moench) varietas lokal rote sebagai hijauan pakan ruminansia pada umur panen dan dosis pupuk urea yang berbeda. Buletin Peternakan. 36(3): 150-155. 
Dewi I, Rinduwati, B. Nohong / Buletin Nutrisi dan Makanan Ternak 14(2) : 41-49

Lingga, P. 2007. Petunjuk Penggunaan Pupuk. Penebar Swadaya, Jakarta. 163.

Silalahi, M. J., A. Rumambi., M. Telleng., W.B Kaunang. 2018. Pengaruh pemberian pupuk kandang ayam terhadap pertumbuhan tanaman sorgum sebagai pakan. Zootec. 38(20): 286-295.

Sriagtula, R., S. Sowmen dan Q. Aini. 2019. Growth and productivity of brown midrib sorghum mutant line patir 3.7 (Sorghum bicolor [L.] Moench) treated with different levels of nitrogen fertilizer. Tropical Animal Science Journal. 42(3): 209-214.

Wantania, D. I., A. Rumambi., W.B. Kaunang. 2018. Pemanfaatan bokashi feses sapi terhadap produktivitas ratun sorgum varietas kawali. Jurnal Zootek. 38(1) : 916. 